\title{
An analysis of the visual results when using toric lenses in cataract surgery
}

\author{
Análise dos resultados visuais na utilização \\ de lente tórica em cirurgia de catarata
}

Astor Grumann Junior', Nayara Teixeira Flügel², Pedro Santa Ritta ${ }^{3}$

\begin{abstract}
Purpose: To evaluate the postoperative results when using the toric IOL during phacoemulsification. Methods: Retrospective cohort based study on the 95 eyes of 67 patients, selected by a census. Analyzed patients with cataracts who had undergone phacoemulsification placement with AcrySof® toric IOL from january 2010 to december 2012. For analysis purposes, it was considered successful when the residual astigmatism was d" 0.75 diopters. The Wilcoxon test for related samples was used to compare non-parametric samples, while the Student T test was used for samples with normal distribution. A p d"0.05 significance level was granted. Results: The average age of the population was $73.00( \pm 10.87)$, there was a higher incidence of females $(56.8 \%)$ and no difference in the side of the affected eye. The average preoperative spherical component was $0.86( \pm 2.89)$, since the average cylindrical component was $-1.53( \pm 1.09)$, with a predominance of the shaft against the rule $(51.6 \%)$. The logarithmic visual acuity (logMAR) preoperative average was $0.32( \pm 0.25)$. The average postoperative spherical component was $-0.02( \pm 0.53)$. Surgical success was obtained in 71 eyes $(74.7 \%)$ having a significant decrease $(p<0.001)$ in the cylindrical component and postoperative logarithmic visual acuity, with the respective values of $0.61( \pm 0.55)$ and $0.08( \pm 0.14)$, with the remaining axis against the rule $(33.7 \%)$. Conclusions: The toric lenses were safe and reproducible with regards to postoperative results and therefore an important option for obtaining excellent final refractometric results.
\end{abstract}

Keywords: Eye; Cataract; Phacoemulsification; Lens implantation intraocular; Elderly

\section{Resumo}

Objetivo: Avaliar os resultados pós-operatórios da utilização da LIO tórica durante a facoemulsificação. Métodos: Estudo retrospectivo tipo coorte de 95 olhos de 67 pacientes, selecionados através de censo. Foram analisados pacientes com catarata, submetidos à facoemulsificação, com colocação da LIO tórica Acrysof®, no período de janeiro de 2010 a dezembro de 2012. No entanto, foram excluídos os que realizaram outro tipo de cirurgia ou tiveram outro tipo de lente para correção da catarata e/ou prontuários incompletos. Considerou-se como sucesso o astigmatismo residual $\leq 0,75$ dioptrias. $\mathrm{O}$ teste de Wilcoxon para amostras correlatas foi utilizado para comparação de amostras não paramétricas, enquanto o Teste t de Student para amostras com distribuição normal. Foi admitido $\leq 0,05$ como nível de significância. Resultados: A média de idade da população foi de $73,00( \pm 10,87)$, com maior incidência do sexo feminino $(56,8 \%)$ e não houve diferença no lado do olho acometido. O componente esférico pré-operatório médio foi de $0,86( \pm 2,89)$, já o componente cilíndrico médio foi de $-1,53( \pm 1,09)$, com predomínio do eixo contra a regra $(51,6 \%)$. A acuidade visual logarítmica $(\log \mathrm{MAR})$ pré-operatória média foi de $0,32( \pm 0,25)$. O componente esférico pós-operatório médio foi de $-0,02$ $( \pm 0,53)$. O sucesso cirúrgico foi obtido em 71 olhos $(74,7 \%)$, havendo uma diminuição significativa $(\mathrm{p}<0,001)$ do componente cilíndrico médio e da acuidade visual logarítmica pós-operatórios, com valores respectivos de $-0,61( \pm 0,55)$ e $0,08( \pm 0,14)$, permanecendo o eixo contra a regra $(33,7 \%)$. Conclusão: As lentes tóricas mostraram-se seguras e reprodutíveis quanto aos resultados pósoperatórios, tornando-se uma opção importante para obtenção de excelência nos resultados refratométricos finais.

Descritores: Olho; Catarata; Facoemulsificação; Implante de lente intraocular; Idoso

\footnotetext{
${ }^{1}$ Clínica de Olhos São Sebastião; Centro Oftalmológico de Diagnose e Terapêutica - Florianópolis, (SC); Hospital Regional São José, São José (SC); Universidade do Sul de Santa Catarina - Palhoça (SC), Brazil;

${ }^{2}$ Universidade do Sul de Santa Catarina - Palhoça (SC), Brazil;

${ }^{3}$ Clínica de Olhos São Sebastião; Centro Oftalmológico de Diagnose e Terapêutica - Florianópolis (SC), Brazil;
}

The study was conducted at Clínica de Olhos São Sebastião and Centro Oftalmológico de Diagnose e Terapêutica - Florianópolis (SC), Brazil

This work was presented as a poster at the Congress of the European Society of Cataract and Refractive Surgeons (ESCRS) from the $5^{\text {th }}$ to the $9^{\text {th }}$ of october, 2013 in Amsterdam in the Netherlands

The authors declare no conflicts of interest

Received for publication: 2/9/2014 - Accepted for publication: 21/10/2014

Rev Bras Oftalmol. 2015; 74 (1): 12-5 


\section{INTRODUCTION}

$\mathbf{T}$ The burden of blindness by cataracts is a major challenge for all countries in the developing world ${ }^{(1,2,3)}$. One third of the population with around 65 years of age have cataracts in one or both eyes, and about $50 \%$ of world blindness is caused by cataracts ${ }^{(2,3,4)}$.

Cataract surgery is the most commonly performed eye surgery in the world ${ }^{(1,2)}$. A rapid change has occurred in the technique used for cataract surgery in all developed countries, with a progressive increase of phacoemulsification and more recently it has been associated with the use of femtosecond laser ${ }^{(5,6,7)}$. These procedures have increasingly gained a refractive purpose, demanding perfect visual results ${ }^{(1,7,8,9)}$.

One of the great difficulties of obtaining this refractive excellence is the existence of a preoperative astigmatism. It is estimated that the pre-surgical corneal astigmatism of 0.75 to 1.50 diopters is present in $41 \%$ of patients ${ }^{(10)}$ and more than 1.50 diopters in $18 \%$ of patients ${ }^{(11,12)}$. In addition, the surgical incision itself can be the cause of a postoperative induction cylinder ${ }^{(6,10,12)}$. As for the options for the correction of astigmatism after phacoemulsification there are various models available of toric IOLs, including the AcrySof ${ }^{\circledR(7,13)}$.

Thus, this study aims to analyze postoperative results when considering the visual acuity, residual refractive error and astigmatism after phacoemulsification, with the implantation of a toric IOL.

\section{Methods}

A retrospective cohort study based on 95 eyes of 67 cataract patients who had undergone phacoemulsification placement with AcrySof® IOL toric (Alcon Laboratories, Inc., Forth Worth, Texas) from january 2010 to december 2012.

The sample was selected by conducting a census which included all the patients of the São Sebastião Eye Clinic, who had undergone phacoemulsification placement with a AcrySof® toric IOL corrective cataract in the Ophthalmological Center of Diagnosis and Therapy, between the $1^{\text {st }}$ january, 2010 and the $31^{\text {st }}$ december, 2012. Both clinics are located in Florianópolis (SC), Brazil. We excluded those who had undergone other types of surgery or who had another type of lens to correct cataracts and/or those with incomplete records.

All phacoemulsifications in this study were performed using the authors' specifiers (a microincision through a $2.2 \mathrm{~mm} \mathrm{IOL}$ is positioned 'in the bag' as previously marked). The biometrics inferometria was performed with the IOL Master 500 and the calculated IOL was performed on site, supplied by the manufacturer. The evaluation of the postoperative results was conducted a minimum of 3 months after phacoemulsification.

For analysis purposes success was considered with a residual astigmatism of $\leq 0.75$ diopters. The results were entered into Excel and exported to the program SPSS 19.0 for analysis and described in the form of absolute and relative frequency for qualitative variables, mean, median and standard deviation for quantitative variables. The comparison of pre-and postoperative data was performed using the Student $\mathrm{T}$ test for normally distributed variables and the Wilcoxon test for nonparametric samples. The level of significance was set at $p \leq 0.05$.

This work is based on Resolution 196/96 of the National
Table 1

Demographic characteristics of the affected eye and of the preoperative corneal astigmatism

\begin{tabular}{lrr}
\hline Variables & n & \% \\
\hline Sex & 95 & 100.0 \\
female & 54 & 56.8 \\
male & 41 & 43.2 \\
Age in years & 95 & 100.0 \\
$48 \leq$ and $<55$ & 4 & 4.2 \\
$55 \leq$ and $<65$ & 20 & 21.1 \\
$65 \leq$ and $<75$ & 28 & 29.5 \\
$75 \leq$ and $<85$ & 27 & 28.4 \\
$85 \leq$ and $<95$ & 16 & 16.8 \\
Affected eye & 95 & 100.0 \\
right & 48 & 50.5 \\
left & 47 & 49.5 \\
Preoperative corneal astigmatism (diopters) & 95 & 100.0 \\
$-7.00 \leq$ and $<-5.00$ & 2 & 2.1 \\
$-5.00 \leq$ and $<-2.00$ & 42 & 44.2 \\
$-2.00 \leq$ and $<0.00$ & 51 & 53.7 \\
\hline
\end{tabular}

Health Council and how research is developed from the analysis of records. As it was not possible to obtain consent to use patient data, there is justification for not using the Informed Consent Form (ICF). Data collection began only after the release of the opinion consubstantiated by the Universidade do Sul de Santa Catarina Ethics Committee (12.101.4.01.III).

\section{RESULTS}

In the period from 2010 to 2012, 95 eyes of 67 patients who were undergoing phacoemulsification with the implantation of AcrySof ${ }^{\circledR}$ toric IOL for the correction of cataracts were analyzed, and of these, there were a higher incidence of females $(56.8 \%)$. The mean and median age of the population was 73.00 $( \pm 10.87)$, ranging $48-94$ years. There was a similar distribution between the affected eye. The preoperative corneal astigmatism ranged from -6.55 to -0.75 diopters with a mean of $-2.19( \pm 1.04)$ and a median of -1.95 , as described in table 1 .

Table 2 shows the variables analyzed at two different times from the same patient before and after phacoemulsification. The mean preoperative spherical component was $0.86( \pm 2.89)$, since the average cylindrical component was $-1.53( \pm 1.09)$, with a predominance of the shaft against the rule $(51.6 \%)$. The logarithmic visual acuity $(\log$ MAR) preoperative mean was 0.32 $( \pm 0.25)$.

Of the 95 eyes examined, the mean postoperative spherical component was $-0.02( \pm 0.53)$. Surgical success (residual astigmatism $\leq 0.75$ diopters) was achieved in 71 of these ( $74.7 \%$ ), with a significant decrease in the mean cylindrical component and postoperative visual acuity logarithmic, with values of -0.61 $( \pm 0.55)$ and $0.08( \pm 0.14)$, remaining predominantly against the axis $(33.7 \%)$.

In the population studied, the potential visual acuity was 0.11 ; however, the postoperative visual acuity was better than that estimated by PAM, 0.08 , as shown in table 3 . This comparison was statistically significant ( $p$ value by Wilcoxon 0.010 ). 
Table 2

Characteristics of spherical and cylindrical refractions, eyesight and axis of astigmatism

\begin{tabular}{|c|c|c|c|c|c|}
\hline \multirow[t]{2}{*}{ Variables } & \multicolumn{2}{|c|}{ Preoperative } & \multicolumn{2}{|c|}{ Postoperative } & \multirow[b]{2}{*}{${ }^{p} \boldsymbol{p}$ value ${ }^{*}$} \\
\hline & Mean (SD) & Median & Mean (SD) & Median & \\
\hline Spherical refraction (diopters) & $\begin{array}{r}0.86 \\
( \pm 2.89)\end{array}$ & 0.75 & $\begin{array}{r}-0.02 \\
( \pm 0.53)\end{array}$ & 0.00 & $<0.001$ \\
\hline Visual acuity(logMAR) & $\begin{array}{r}0.32 \\
( \pm 0.25)\end{array}$ & 0.30 & $\begin{array}{r}0.08 \\
( \pm 0.14)\end{array}$ & 0.00 & $<0.001$ \\
\hline Cylindrical refractive(diopters) & $\begin{array}{r}-1.53 \\
( \pm 1.09)\end{array}$ & -1.50 & $\begin{array}{r}-0.61 \\
( \pm 0.55)\end{array}$ & -0.50 & $<0.001$ \\
\hline Axis of astigmatism(degrees) & $\begin{array}{r}95.79 \\
( \pm 50.85)\end{array}$ & 90.00 & $\begin{array}{r}63.79 \\
( \pm 59.48)\end{array}$ & 60.00 & $<0.001$ \\
\hline
\end{tabular}

$(*) p$ value by Wilcoxon Test

SD: standard deviation

logMAR: logarithmic visual acuity

Table 3

\section{Features of PAM and postoperative visual acuity}

\begin{tabular}{lrr}
\hline Variables & Mean (SD) & Median \\
\hline PAM (logMAR) & $0.11( \pm 0.16)$ & 0.09 \\
Visual acuity afteroperative $(\log M A R)$ & $0.08( \pm 0.14)$ & 0.14
\end{tabular}

SD: standard deviation

logMAR: logarithmic visual acuity

PAM: potential visual acuity

\section{DISCUSSION}

Cataract surgery with IOL implantation is one of the most common surgical procedures in the world. The replacement of the opacified lens with a transparent artificial IOL allows the correction of the refraction error of the patient.

In the present study, it demonstrated a greater frequency of cataract surgery in female participants, similar to many recently published works ${ }^{(8,10,14,15,16,17,18)}$. This analysis may be related to two factors: women's greater concern for their health, therefore seeking more medical care and the longevity of eldery women.

Regarding the age of the participants, it is evident that the cataract is a disease related to aging (mainly from the age of $60)$. Studies such as Acharya et al. ${ }^{(4)}$ claim that almost half of the elderly in developing countries, have a clouding of the lens.

The preoperative corneal astigmatism, there was a tendency of lower values, with a mean of -2.19 , similar to studies such as Ahmed et al. ${ }^{(10)}$ of -1.70 , and Lee et $\mathrm{al}^{(18)}$, of -1.76 . However, the study by Hoffmann et al. ${ }^{(17)}$ observed higher values of corneal astigmatism before surgery, -3.55 . This difference, compared with the research cited above, is due to the fact that in the latter, very young patients were included (from 32 years), resulting in refractive surgery and cataract correction not having larger cylindrical values.

The refractive results, there was a significant decrease of the residual degree after surgery in both the spherical and the cylindrical component, with a tendency to emmetropia. The logarithmic visual acuity showed a significant improvement in vision after phacoemulsification, tending to normality. With the improvement of cataract surgery, ocular incisions to extract the opacified posterior lens and IOL placement are becoming smaller, generating less postoperative astigmatism and, consequently, with less variation in the axis of astigmatism.

All of these statistically significant findings seem to support the reasoning of worldwide literature ${ }^{(8,15,17,18,19)}$. Except the axis of astigmatism, which varies greatly between studies, as in Ahmed et al. ${ }^{(10)}$, that preoperatively the trend was in favor of the rule and after phacoemulsification it became the majority against the rule. This can be explained by the fact that patients in this survey were mostly young, so the axis tends to be in favor of the rule preoperatively. Moreover, in this study, patients are mostly elderly, therefore the shaft tends to be against the rule before surgery with the tonicity of the lid and/or alterations of the cornea.

In addition, ophthalmic surgery is, by its very nature a variable procedure, from eye to eye and from surgeon to surgeon, and this can have a significant effect on results. Some of the factors that can change the axis of astigmatism is the process of marking the cornea, to properly align to the toric lens; the size and location of the incision for the extraction of the natural crystalline lens and IOL placement; the shaft alignment achieved at surgery and the rotation of the lens during the postoperative period.

Regarding the potential visual acuity, this had a better $\log$ MAR value than expected after placing the toric IOL, the PAM in most cases, underestimated the visual acuity after phacoemulsification.

As Chiacchio et al. ${ }^{(20)}$ have reported, PAM has some limitations, as it requires a good understanding of the patient 
being examined, the resources and the need for transparency. It is therefore not a good method for dense cataracts. However, its use as a preoperative examination for the function of only revealing an estimate of the postoperative visual acuity, should not be the determining factor in the indication or contraindication of the surgical procedure, but as another parameter that should be added to the picture of the clinical patient.

In this work, with regard to surgical success (residual astigmatism $\leq 0.75$ diopters), the majority of patients ( 71 eyes) who had undergone phacoemulsification with IOL placement toric AcrySof ${ }^{\circledR}$ had a significant improvement in vision in relation to the spherical and cylindrical refractions, therefore becoming less dependent on glasses, especially for distance vision. According to literature, the primary cause of failure in the use of toric IOLs is the rotation within the capsular bag. In this research it was not possible to confirm this finding, as due to the patients older age there was unsatisfactory pupil dilation and even under mydriasis medicine it was not possible to observe the IOL markings in the vast majority of them.

\section{Conclusion}

The present study showed that toric IOLs are an alternative for the correction of refractive errors and astigmatism in cataract patients. Its results are predictable and reproducible therefore becoming an important option for achieving excellence in refractometric results, providing an improved final vision and hence a better quality of life for the patients.

\section{RefERENCES}

1. Aghaji AE, Natchiar G. Structured extracapsular cataract extractionintraocular lens microsurgical training: Report of a trainee's experience. Niger J Clin Pract. 2011;14(1):71-3.

2. Marback R, Temporini E, Kara Junior N. Emotional factors prior to cataract surgery. Clinics. 2007;62(4):433-8.

3. Temporini ER, Kara Junior N, José NK, Holzchuh N. Popular beliefs regarding the treatment of senile cataract. Rev Saúde Pública. 2002;36(3):343-9.

4. Acharya RU, Yu W,Zhu K, Nayak J,Lim TC, Chan JY. Identification of cataract and post-cataract surgery optical images using artificial intelligence techniques. J Med Syst. 2010;34(4):619-28.

5. Kara-Junior N,Santhiago MR, Parede TR, Espindola RF, Mazurek MG, Germano R, Kara-Jose N. Influência da correção cirúrgica da catarata na percepção laborativa. Arq Bras Oftalmol. 2010;73(6):491-3.

6. Hida WT, Motta AF, Inomata DL, Jales MQ, Facio Junior AC, et al. Incisões relaxantes limbares ou incisões no meridiano mais curvo associadas a facoemulsificação com implante de lente intra-ocular multifocal: relato de três casos. Arq Bras Oftalmol. 2008;71(2):273-7.
7. Medeiros HA, Medeiros JE, Baldiotti JL. LIO pseudofácica suplementar sulcoflex ${ }^{\circledR}$ toric sobre LIO acrysof ${ }^{\circledR}$ toric. Rev Bras Oftalmol. 2013;72(5):344-7.

8. Zarranz-Ventura J, Moreno-Montañés J, González-Jáuregui JC, Fernández-Yáñez EN, Sádaba-Echarri LM. Implante de lentes intraoculares tóricas Acrysof ${ }^{\circledR}$ encirugía de la catarata. Arch Soc Esp Oftalmol. 2010;85(8):274-7.

9. Hill W, Potvin R. Monte Carlo simulation of expected outcomes with the AcrySof ${ }^{\circledR}$ toric intraocular lens. BMC Ophthalmol. 2008;8:22.

10. Ahmed IIK, Rocha G, Slomovic AR, MD, Climenhaga H, Gohill J, Grégoire A, Ma J. Visual function and patient experience after bilateral implantation of toric intraocular lenses. J Cataract Refract Surg. 2010; 36(4):609-16.

11. Entabi M, Harman F, Lee N, Bloom PA. Injectable 1-piece hydrophilic acrylic toric intraocular lens for cataract surgery: Efficacy and stability. J Cataract Refract Surg. 2011;37:235-40.

12. Ruíz-Mesa R, Carrasco-Sánchez D, Díaz-Álvarez SB, Ruíz-Mateos MA, Ferrer-Blasco T, Montés-Mico R. RefractiveLens Exchange withFoldableToric Intraocular Lens. Am J Ophthalmol. 2009;147(6):990-6.

13. Visser N, Ruíz-Mesa R, Pastor F, Bauer NJ, Nuijts RM, Montés-Micó R. Cataract surgery with toric intraocular lens implantation in patients with high corneal astigmatism. J Cataract Refract Surg. 2011;37(11):1403-10.

14. Correia RJB, Moreira H, Netto SUL, Pantaleão GR. Performance visual após implante de LIO tórica em pacientes com astigmatismo corneano. Arq Bras Oftalmol. 2009;72(5):636-40.

15. Centurion V,Lacava AC, Caballero JC.A neutralização do astigmatismo corneano durante a cirurgia da catarata por meio de lente intraocular tórica: resultados. Rev Bras Oftalmol. 2009;68(2):76-82.

16. Alió JL, Agdeppa CC, Pongo VC, Kady BE. Microincision cataract surgery with toric intraocular lens implantation for correcting moderate and high astigmatism: Pilot study. J Cataract Refract Surg. 2010;36(1):44-52.

17. Hoffmann PC,Auel S, HützWW. Results of higher power toric intraocular lens implantation. J Cataract Refract Surg. 2011;37(8):1411-8.

18. Lee JY, Kang KM, Shin JP, Kim IT, Kim SY, Park DH. Two-year results of AcrySof toric intraocular lens implantation in patients with combined microincision vitrectomy surgery and phacoemulsiûcation. Br J Ophthalmol. 2013;97(4):444-9.

19. Mendicute J, Irigoyen C, Aramberri J, Ondarra A, Monte's-Mico R. Foldable toric intraocular lens for astigmatism correction in cataract patients. J Cataract Refract Surg. 2008;34(4):601-7.

20. Chiacchio BB, Sato RM, Siqueira RB, Marques FF. Fidelidade do "potential acuity meter"(PAM) no prognóstico da acuidade visual pós-operatória de cirurgia de catarata. Arq Bras Oftalmol. 2008;71(6):805-8.

\section{Corresponding author}

Astor Grumann Junior

Rua Doutor Arminio Tavares, $\mathrm{n}^{\circ} 77$ - Centro

Florianópolis (SC), Brazil

Tel: (+548) 3222-4866

E-mail: astor@uol.com.br 